\title{
The Symbolic Meaning of Waju Tokko in Bone Regency: A Semiotic Analysis
}

\author{
Andi Hilda Sya'ban ${ }^{1}$ and Andi Filsah Muslimat ${ }^{2}$ \\ \{1andihildasyaban@yahoo.com, ${ }^{2}$ andifilsahm@yahoo.com\} \\ ${ }^{1,2}$ Hasanuddin Unversity
}

\begin{abstract}
The research aims to find out the symbolic meaning of waju tokko based on the semiotic analysis perspective in Bone Regency. The research is a descriptive reasearch which using qualitative analysis method. The writer tries to describe generally about the researched object by collecting data and information as much as possible about conditions and facts that is happening during the research. The result is the symbolic meaning of waju tokko is observable from the color of the cloth worn by the noble lady in Bone Regency. The yellow color was chosen as the noble color because when Tomanurungnge ri Matajang first time showed up on the earth, she wore a cloth in a shade of yellow. Finally, the yellow color represents expensive and valuable gold just like women. Expensive representation on Buginese women's clothes do not make them arrogant. The meaning of valuable aspect of the clothes' color is a woman who wears them does not easily attempt by worldly desires. Whilst the meaning of valuable is depicted in an 'elong' "'bunga-bunga lise' sunrong, masuli masagala patta'bakkaengngi. Bunga-bunga tenrong salo, iyapa na ta'bakka tudappi guru e". the story of the 'elong' is about a girl whom is not easy for a man to marry her. The man can only marry her if he can fulfill her physical and spiritual needs. the sentence Iyapa na ta'bakka tudappi guru e means the girl will be free from restrictions after getting married.
\end{abstract}

Keywords: Waju tokko, semiotic

\section{Introduction}

The national costume of Indonesia is a part of national culture which is special and quality culture from ethnic groups in Indonesia. the specialty according to Ki Hajar Dewantara is considered as the peak of local cultures which can be self identified and make people proud [1]. On the beginning, clothes are worn to cover or protect parts of a body from a surrounding environment. But from time to time the clothes have become attributes to recognize the social status, the culture, and the conditions of certain locations. That is why there are a lot of variations of the national costumes in Indonesia.

There are some factors that caused the appearance of national costumes. those factors covers geographical aspects, cultural aspects, and religious aspects. The geographic conditions in certain areas will affect the clothes of specific cultures. For example the area which has a high air temperature usually fashions the costume from the area with a low air temperature. 
The cultural aspects are also influental toward the variety of the national costumes of Indonesia. As an example, in Minangkabau a leader wears black clothes to express leadership. Besides other equipment such as a kris cannot be used by people except the leader in Minangkabau. The kris as an attribute means that the leader must think of an act thoroughly before doing it. Then the leader must not be emotional on facing a trouble. The religious aspects also take effect on the characteristics of the national costumes. The aspects are influental because Indonesian citizens are known as religious people. It also shows on the first principle of the foumdational philosophical theory of Indonesia (Belief in the One and Only God). Therefore, it is not surprising if the majority of the national costumes of Indonesia are more closed than other countries[1]. By looking on the aspects mentioned before, the author interests to do the research on the costume of South Sulawesi specifically on the buginese ethnic group in Bone regency. The differences on the social life are possible because of a background of history. The diversities of cultural elements among ethnics in South Sulawesi are shown on the living necessities such as the national costumes including the attributes of the costumes.

\section{Research Method}

The research method used in this research is descriptive qualitative research. Data obtained such as observations, interview results, photo shoots, document analysis, field notes compiled by researchers at the research location, are not set forth in the form and figures. Researchers immediately conduct data analysis by enriching information, looking for relationships, comparing, finding patterns on the basis of the original data. The results of data analysis in the form of presentations about the situation under study are presented in the form of narrative descriptions. Qualitative research tends to rely on the strength of the senses of the researcher to reflect cultural phenomena. This sense observation is considered more accurate to see cultures that tend to change with the changing times. This change is certainly difficult to measure and averaged using a quantitative paradigm[2]. Research on the meaning of waju tokko's philosophy means that the data collected comes from the real environment and the situation is, namely direct dialogue with informants relating to this research. While the method used to analyze the data in this study uses descriptive methods. This is caused by the data collected being analyzed and presented descriptively. Descriptive research methods have several characteristics, among others, do not question the right or wrong of the object being studied, the emphasis on the actual symptoms or on what happened at the time the study was conducted and is usually not directed to test the hypothesis. Vice versa with perspective research methods. This is in line with the opinion of Arikunto [3] which states that descriptive research is not intended to test a particular hypothesis, but only describes what it is about a variable, symptoms or circumstances.

\section{Results And Discussion}

National costumes are characteristics of Indonesian Culture which have special meanings. The costumes are potraits of the country's motto Bhinneka Tunggal Ika. Indonesian people must regard and keep the cultural characteristics. they must believe the culture of Indonesia cannot be extinguished. South Sulawesi is a region that is rich with cult and customs. The 
people still respect the heritage of their ancestors by keeping and preserving the culture in the area. One of them is waju tokko. Waju tokko is specifically used by the Bugis community.

The cloth used to make waju tokko is called the muslin cloth in Europe. In different places the cloth has a different name. In Greece this cloth is called maisolos, in East India it is called the masalia cloth, and in Arabic it is called the ruhm cloth. While in Dhaka, a city in Bangladesh, is the first city producing and selling this cloth. In the book The Travel of Marco Polo it is explained that the Muslin fabric is made in Mosul (Iraq) and sell by a merchant called "Musolini". This is interesting because the people of South Sulawesi are already familiar with the cloth and wear this type of cloth compared to European people, who only know it in the XVII century. This cloth is only popular in France in the XVIII century [4]

In addition to functioning as a protector and identity of the Bugis community in the past, Waju tokko also has other functions, the functions that reflect elements of the Buginese culture. The functions are:

1) Ethical Function

Waju tokko has provisions when wearing it. For example the wearer must pay attention to the number of bracelets used, the color of the cloth of waju tokko, and so on.

2) Aesthetic Function

The beauty of waju tokko, both from its shape, color and decoration is very interesting. the use of jewelery in various shapes and colors aims to create beauty that please the eye. Jewelry made of gold and silver for women, or songkok decorated with gold thread for men, adds the sense of beauty, both by the wearer and those who look at it.

3) Religious Function

The majority of the Bugis are Muslim. Therefore, the Bugis traditional costume, waju tokko, tends to show the use of clothing with a tendency according to Islamic law. The teachings of Islam to cover certain parts of the body are also applied to waju tokko which is only in the form of a thin cloth showing the chest, now it is modified into a thick and stiff fabric. According to Nurhayati [5] in her book Cinta, Laut dan Kekuasaan dalam Epos La Galigo, this is influenced by the culture and traditions of the Buginese people who are not frozen and closed. Because of its flexibility and its closeness, it is possible for Buginese people to progress and develop themselved. So customs and traditions are still maintained, but they are very open to renewal, as long as they do not change the basic essence and ideological content in their culture. As an example, we can see the highest law of the Buginese, namely pangngadereng.

4) Social Structure

Determining the shape and color of waju tokko is a level of identity of wearers that has been practiced by the Bugis community in the past, such as office clothes, religious offices, upperclassmen, middle class and others. These provisions reflect the social status of waju tokko.

5) Symbolic Function

The traditional clothes of the Bugis people who are usually worn during the wedding ceremony are a symbol of the ideal concept by parents and family so that the new household will grow into a prosperous and happy household. Therefore, a bride and a groom is symbolized as the king and the queen of the day. In addition there are also those who symbolize the clothes as certain meanings. For example, the colors used by girls or virgins are different from the colors used by married women.

In the early 19th century, Don Lopez Comte de Paris, a loyal servant of Governor General Deandels, introduces a breasts cover which is called "kutang" by Javanese women in Indonesia, but it is unfortunate that this cover is not yet popular in the land of Bugis-Makassar. 
So it is not strange if in the 1930s, there are still many Bugis-Makassar women wearing bodo clothes without wearing a breasts cover [6].

Baju bodo is a formal cloth for Buginese woman in the form of semi-transparent Bugis silk blouses. Baju bodo is only dyed in one color, sewn like a pillowcase, head and arms open. baju bodo is usually paired with gold jewelry and a silk sarong. The sarong is only tied to the waist, and the rest of the cloth is held by the left hand. Because wearing baju bodo expresses respect, baju bodo is always worn when a woman participates in a gift-giving ceremony, especially if the gift is for a nobleman. Baju Bodo is dyed in green, red, dark red or black dye (among other colors) whose use is limited to aristocrats of a certain level, age, and status. But now women can wear any color, as a variation on new baju bodo as they wish. When a highranking female aristocrat wears colored baju bodo, traditionally she has the right to be waited on at a party. Most other female guests avoid using that color, because they are considered disrespectful because the only people wearing these colored clothes are noble women. Even so most modern women wear the colors they like now [7].

Along with the development of the era and the introduction of Islam in South Sulawesi, baju bodo is changing little by little but it still has its own characteristics. The material is no longer using muslin cloth but it use rather thicker and stiffer fabrics so it does not reveal the curves of women's bodies. With the use of this thick, rigid cloth, the name of baju bodo has changed to waju la'bu. In the Bugis area, baju bodo are also called waju tokko.

One of the things that distinguishes humans from animals as God's creatures is the social function of the human body that is not found in animals. So, it's not because the human body is very different from animals, but because humans live in a social environment that is different from animals [8]. Nevertheless, as a work, culture contains an ideology that has never changed in it. According to Pelras, the continuity of a nation's cultural identity is no different from individual human lives. Humans always experience changes from infancy to adulthood. physical characteristics always change but spiritual characteristics are always the same. Likewise with culture, it may change its form, in terms of its politics and religion, but its cultural values remain unchanged [9].

Ideologies hide in myths. According to Barthes in his book titled Mythology: it is a part both of semiology in as much as it is formal science, and of ideology in as much as in historical science: it studies ideas-in-form. Mythology is the science of formal ideas which consists of two parts, the first part is semiology as part of formal science and the second is ideology as the science of history. According to Barthes from the semiology system, if the meaning of the text in the second stage has been well established for its acceptance in a society, then it has been transformed into an ideology of society [10]. He also believes that a sign system reflects the assumptions of a particular society in a certain time. Semiotics, or in Barthes's term semiology, basically wants to learn how humanity defines things. in this case interpret (to sinify) can not be confused with communicating (to communicate). Interpreting means objects not only carry information, in which case the objects are to be communicated, but also constitute a structured system of signs. One of the important areas that Barthes encompassed in his study of the sign is the role of the reader. although connotation is the original nature of the sign, it requires the activeness of the reader for the connotation to function. Barthes straightforwardly reviews what he often refers to as the second level of meaning system, which is built on another existing system. this second system by Barthes is called connotative, which in the book Mythologies expressly distinguishes it from the denotative or first level meaning system. In the book Mythologies also Barthes illustrates the approach to the study of signs (semiotic). According to him the signs in culture are not something that is innocent or pure but the sign has a complex relationship with the 
reproduction of ideology [10]. In connection with this matter, in this study the writer examine the meaning of waju tokko by using a semiotic analysis by Rolland Barthes.

As said by Zoest [11], semiotics is a branch of science that deals with the study of signs and everything related to signs, such as the sign system and the processes that apply to the use of signs. This was explained also by Sudjiman [12] that semiotics is the study of signs and everything related to them, how they function, their relationship with other signs, their delivery, and their acceptance by those who use them.

In the book The Fashion System, Barthes talked a lot about the world of fashion. In this book Barthes also discusses the operation of the signifier mode structure, its signified structure, and the sign structure or its significance. Indeed, the study of fashion or Barthes fashion is inseparable from the field of semiotics which he has been developing.

This study examine the "Symbolic Meaning of Waju Tokko in Bone Regency". the researcher used the study of Roland Barthes's semiotics. Semiotics examines a garment as a social function. Every clothing worn is seen as a sign. In structural semiotics (Barthes), fashion is a "sign" (signifiant) which has a "sign" (signifie), which is a specific meaning. This meaning can develop into "connotation" based on the cultural background of the connotation provider. If the connotation continues for some time depending on its intensity, then "myths" will form which will be able to continue to become "ideologies". Thus, semiotics also see the body with nudity as a marker that has certain markers. Barthes' theory is a dynamic structural theory, but it remains dichotomous. All of them rely on abstract "structures" formed first in human cognition [6].

If clothing is the object under study (cultural manifestations), then we examine it by looking at it from three dimensions. The first dimension (body) is the clothing as a concrete thing that is understood by its form and its function, for example headgear (hat, cap, and veil), lower body cover (skirt, sarong and trousers), or footwear (sandals, slippers and terompah). The second dimension (mind) is how the clothes are understood by those who interpret or see them, for example Javanese bridal ceremonial clothes, casual clothes, dance clothes, and clothes for office work. Furthermore, in the third dimension (culture) what is understood by one person through social networks of understanding also becomes the knowledge for other community members, so that if there is a mismatch in the use of clothing, social sanctions will occur [6].

At first waju tokko is known as waju bodo which means short. But after the cloth of waju bodo is changed from muslin to thicker cloth, the name changed to tokko. This is because the shape of the body is transparent so that it shows curves. After the teachings of Islam entered the Bugis land, the subject of waju bodo became a conversation. people think about how to change the bodo image into an appropriate outfit according to Islamic teachings but do not eliminate the characteristics and shape. Therefore, an idea emerged that waju bodo can be transformed into a thicker cloth by the way the cloth is soaked into water, then it is washed with starch by tapping evenly. Furthermore, the cloth is being stretched on a bamboo that is placed transversely as a hanger. At the bottom of the shirt is also fitted with bamboo crosswise and at both ends are given stones as ballasts. The shirt is patted until the starch is completely, evenly distributed. The cloth is dried under the sun and aerated until the cloth is hard and slippery so it appears that the cloth has been ironed. That is why waju tokko is not transparent, the fabric is thicker and the fabric is mixed with starch so the fabric hardens and appears stiff.

Waju tokko which is used by aristocratic women is made from real silk. Waju tokko made from original silk must be woven and then dried in the sun so that the quality of the clothes is maintained, in contrast to waju tokko made from organdy and other materials after use, can be washed immediately while those made from original silk cannot be washed. According to a 
humanist in Bone named Asmat Riayadi, waju tokko is initially introduced in Bone by the 10th King of Bone, We Tenri Tuppu matinroe ri Sidenreng.

Waju Tokko is a garment adapted from Chinese clothing. This is because before the Dutch entered the Bugis land, Chinese traders has already set foot on the Bugis land. Chinese clothing women is called cheongsam or qipao which means long clothes. However, the cheongsam used to have two parts: a long shirt and a skirt. Short-sleeved clothes that are adapted by the Bugis first to be used as everyday clothing. Even so, cheongsam isn't exactly the same as waju tokko. Cheongsam has sleeves that are about three quarters in length while waju tokko has no sleeves at all. In addition cheongsam is also made of silk fabric with a variety of patterns and motifs, while Waju Tokko is made of thick stiff fabric and has no motive at all.

Asmat Riyadi, a humanist from Bone, revealed that Waju tokko is a special choice of name for Bugis traditional clothing. The shape is the same as waju bodo but the thing that distinguishes waju tokko with waju bodo, it is made by mixing the fabric with starch so that the fabric looks stiff. The shape is a simple symmetrical cut. When waju tokko is worn, it looks bubbly and loose. It is true that at the beginning waju tokko is made of a very thin cloth, but as the introduction of Islam in Bone, the structure of clothing has to change according to Islamic law.

Tokko comes from the word pokko which means it does not have sleeves because if it being examined carefully this shirt does not have sleeves. With the development of technology and knowledge about fashion, waju tokko is not immune from changes. In the past, the pace of tokko is not as short as today. the cloth is long below the knee. Asmat Riyadi explains that Fatimah Bandri, a female king in Bone, cut off waju tokko she is wearing because she feels that the clothes she is wearing is very long and limited her movements. Fatimah Bandri is famous for her creativity and intelligence. She likes learning to dance and to hunt. she knows many traditional dances, such as pa'joge dance and pattennung dance. These two activities that require flexibility in moving encourage Fatimah Bandri to cut waju tokko she wears, so people follow the king to cut their clothes.

In Soppeng waju tokko used by aristocrats is green. It is different with aristocrats in Bone. Bone aristocrats use yellow waju tokko. In ancient times when To Manurungnge ri Matajang first appeared on earth she is wearing yellow clothes. The umbrella she used is yellow and so were the two ladies who accompanied her they wear clothes in yellow.

Yellow is chosen as the color of the clothes of the aristocratic people in Bone because yellow has a symbolic meaning that women who wear yellow clothes are expected to have warm attitude like the morning sun, as cheerful as a blooming sunflower, friendly to the surrounding environment and yellow is also assosiated with gold. It is known that gold is a very expensive and valuable item. being a Bugis Bone woman she must have an "expensive" nature but that does not mean she has to be arrogant. That is, she should not be easy to be tempted with all worldly passions.

The symbolic meaning for "valuable" is described in elong "bunga-bunga lise' sunrong, masuli masagala patta'bakkaengngi. Bunga-bunga tenrong salo, iyapa na ta'bakka tudappi guru e". The meaning contained in bunga-bunga lise' sunrong and bunga-bunga tenrong salo are said to be a girl. It is difficult to marry the girl and not just anyone who can marry her except a man who has been able to take care of her needs physically and mentally." Iyapa na

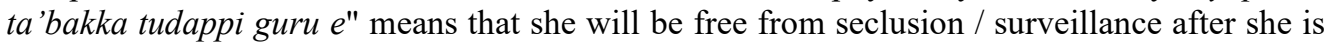
married. Generally people or tau sama mostly use the green color waju tokko. In connotative meaning, green in the life of the Bugis community has a philosophical meaning such as virginity, fertility, growth, fragrance, freshness, hope and resurrection. On this basis, we can 
arrive at a deeper understanding of the sign. The ancient Bugis has hope for their offspring who wear green shades of waju tokko so that they could grow into women of good character, able to rise from all the plight that plagued them through life. Fragrance means that Bugis women are able to uphold the good name of their tribe with achievements and credibility in their work. White color waju tokko is chosen for a host or Bugis people used to call it Indo' Pasusu. In the past, a consort is not allowed to provide breastmilk so a host is chosen to breastfeed the crown prince. In addition to Indo' Pasusu there is also what is called bissu. According to previous beliefs, bissu is considered to have no sex organs so she does not have lust. This can be interpreted that bissu is considered sacred.

Society is always developing and changing. Developments and changes cover broad aspects because the development of one aspect also brings progress to other aspects. Likewise with waju tokko, these clothes change over time. Waju tokko is no longer the same as now. This is due to the changing time and space dimensions. There several changes occur in the use of waju tokko, for example, starting from the most basic thing like color and the most important is the wearer of waju tokko itself whose usage is determined based on the social level of the wearer. Waju tokko is currently made from a variety of materials and models that have been modified. Some people have modified it by adding beads or shiny stones on the chest to make it look more modern.

In addition to the changes above, there has also been a change in the form of the waju tokko which is only in the form of a sleeveless shirt. Now many designers are modifying it by making the sleeves look longer to make them look attractive. they make the clothes not too exposed so that people who wear hijab can wear them. they are beautiful and they do not outdated. How to use waju tokko is also different now. In the past people wear waju tokko with lipa' sabbe. In use of it, the lipa' sabbe is inside waju tokko and is not bound around the waist but it is sandwiched between the arms and waist. The Bugis people call it "dikingking". This is because the Bugis woman is forbidden to raise her arms up high. However, now the Bugis people are rarely doing that. Usually, the wearer uses a silk sarong or batik cloth as a pair of modified waju tokko and her clothes are left hanging down [13].

\section{Conclusion}

After the research that has been carried out in depth, some conclusions can be drawn about "the Symbolic Meaning of Waju Tokko in Bone Regency" as follows, yellow waju tokko is worn by noble woman in Bone Regency. That is because when To Manurungnge ri Matajang first appeared on earth she is wearing yellow clothes, as well as her escorts . Besides the yellow color has a philosophical meaning which is women who wear yellow clothes are expected to have warm attitude just like the morning sun, cheerful like a blooming sunflower, friendly to the surrounding environment. The yellow color also has association with gold as it is known that gold is an expensive item. A Bugis woman is like gold. Then, the rules regarding the use of waju tokko and how to use it have changed a lot. These changes can be seen clearly in the form of shape, color, size, and variations. If in the past waju tokko is used based on age or social strata, now the rule is no longer used as a reference. Waju tokko is now free to be used by anyone by all circles of life and ages. This can be seen from women who use waju tokko at wedding parties but they wear it by using color choices that are not in accordance with the rules that used to be. 


\section{References}

[1] D. P. dan Kebudayaan, Busana Adat Pada Masyarakat di Sulawesi Selatan. Makassar: Tim Penulis Depdikbud, 1990.

[2] S. Endaswara, Metodologi Penelitian Kebudayaan. Yogyakarta: Gdjah Mada University Press, 2006.

[3] Arikunto, Posedur Penelitian Suatu Pendekatan Praktik. Jakarta: Rineka Cipta, 1990.

[4] M. Rugoff, The Travels of Marco Polo. USA: Penguin Book, 1961.

[5] N. Rahman, Cinta, laut dan Kekuasaan. Makassar: La Galigo Press, 2006.

[6] R. Sylado, Novel Pangeran Diponegoro menggagas Ratu Adil. Jakarta: Tiga Serangkai, 2007.

[7] S. B. Millar, Perkawinan Bugis. Makassar: Ininnawa, 2009.

[8] B. H. Hoed, Semiotik dan Dinamika Sosial Budaya. Jakarta: Komunitas Bambu.

[9] C. Pelras, Sulawesi Selatan Sebelum Datangnya Islam Berdasarkan Kesaksian Bangsa Asing. Jakarta: Archipel, 1985.

[10] R. Barthes, Myth Today dalam Mythologies. Frogmore, St. Albans, Herts A12 2NF: Granada Publishing Limited, 1973.

[11] A. Van Zoest, Semiotika: Tentang Tanda, Cara Kerjanya, dan Apa yang Kita Lakukan Dengannya. Jakarta: Yayasan Sumber Agung, 1993.

[12] Sudjiman, Panuti, and A. Van Zoest, Serba-Serbi Semiotika. Jakarta: Gramedia Pustaka Utama, 1992.

[13] S.T. Widodo and K. Saddhono. "Petangan Tradition In Javanese Personal Naming Practice: An Ethnoliguistic Study." GEMA Online ${ }^{\circledR}$ J. of Lang. Stu. vol. 12 no. 4 pp 1165-1177, 2012 